\title{
Status of Primary Market Response in Nepal
}

\author{
Jas Bahadur Gurung
}

\begin{abstract}
This paper attempts to analyze the status of primary market response in Nepal using secondary data collected from annual reports of various capital market institutions of 22 years starting from 1993/94 to 2014/15. This paper follows descriptive research design and analysis has been carried out throughout accordingly. The study concludes that the total capital mobilization has been increasing during the study period implying there is transfer of capital from surplus sectors to the productive investments gradually. Ordinary shares including rights offerings has found more active in the primary market than that of other alternative market mechanisms. It means preference shares, debentures, mutual funds and citizen unit schemes have been found still unorganized in Nepal. initial public offerings is mainly dominated by the ordinary shares has been highly oversubscribed during the study period except in few cases. This particular case shows the public response towards primary market is found good. However, when we go through all other indicators the primary market has still found unsystematic, vulnerable and even small in size. There are a very limited number of merchant bankers as financial intermediary in the primary market. The liberalization policy has brought major changes in regulatory and institutional framework but the primary market has yet to be improved and advanced so that the corporate houses can benefit by designing optimum capital structure and investors are also benefitted by developing appropriate investment portfolios. More specifically, the primary market more dynamic ofter the introduction of federal republic system since 2006/07 in Nepal, though it is still unstable.
\end{abstract}

Keywords: Capital mobilization, capital structure, initial public offerings, registration, subscription,

The growth of output in any economy depends on the increase in the proportion of savings and investments to a nation's output of goods and services. The mobilization of savings and investments is possible through the financial system and financial institutions (Machiraju, 1998), called financial market. Economic growth and development of any economy by and large, depends on the existence of a well-functioning of financial market. The prime function of financial market is to facilitate the transfer of funds from surplus sectors to deficit and/or productive sectors of the economy.

Primary market is one of the major segments of financial market that deals in securities issued originally by the companies. The proceeds from the issue or sale of securities in this market are the major source of long term finance for the establishment and operation of the company (Paudel et. al. 2013). Merchant banker or issue manager assists as a financial intermediary that brings issuing company and potential investor together indirectly to trade in the primary market. Securities once registered for public issue, merchant bankers float them in the primary market and trading takes place that may be equal to, above or below the issued volume of securities. Therefore, this paper attempts to analyze the status of primary market response in Nepalese financial market. 


\section{Theoretical Framework}

Primary market is the market place where securities are sold to mobilize the savings for the establishment and operation of the business (Bhattarai, 2064). Corporate enterprises which are desirous of raising capital funds through the issue of securities, approach the primary market (Gurusamy, 2011). It mainly deals in long term securities like equity and debt. The main vehicle in the primary market is the Initial Public Offering (IPO), the first public sale of a company's securities. It also provide a forum for the sale of new securities, called seasoned new issues, by companies that are already public (Gitman \& Joehnk, 2012). Machiraju (1998) states that in the primary market new issues of equity and debt are arranged in the form of a new floatation, either publicly or privately or in the form of a rights offer to existing shareholders. Companies raise new cash in exchange for financial claims like shares or debentures or both. Public sector undertakings also issue security for long term fund is called bond. The transactions in the primary market, however, result in capital formation.

In the primary market, a company has three choices as, a) a public offering, b) a rights offering, and c) a private placement (Gitman \& Joehnk, 2012). When a company decides to go public, it must find a merchant banker willing to underwrite the offering that is responsible for promoting the securities and facilitating the sale of company's IPO securities. In case of very large issues, the merchant banker brings in other banks as partners who shares the financial risk associated with buying the entire issue called underwriting syndicate (Bhattarai, 2064). They are all selling groups of securities. Merchant bankers generally provide three basic services as, a) advice and counsel, b) underwriting, and c) distribution.

In primary market, securities are sold either at par or premium or at discount. But in case of Nepal, Company Ordinance 2005 has restricted to sell or issue securities at discount. However, trading takes place that may be equal to, above or below the issued volume of securities. If the issued securities (equity share mainly in case of Nepal as it dominates the transactions in the securities market) are undersubscribed, then the problems of allotment do not arise. But in case of oversubscription, the available shares can not satisfy all the applicants. In such situation, the company may i) reject the excess application in full, ii) allot proportionately to all applicants, iii) reject some applications and allotment may be made proportionately to the rest applications (Mukharjee \& Hanif, 1998).

As the company grows, needs additional funds for the expansion of its activities. Corporate enterprises may raise additional capital through rights issue. Under this the existing company issue shares to its existing shareholders in proportion to the number of shares already held by them (Guruswamy, 2011). It is a kind of further issue often offered at par. Right offering affects the share price in the secondary market because it has some value. Normally the price of share increase before right offering and decreases after the issue of right share (Gurung, 2012). When company made further issue of securities to the public for raising additional capital, the price of securities is relatively higher than the par value.

When accumulated reserves and surplus of profits of a company are converted into paid up capital, it takes the form of issue of bonus shares. It merely implies capitalization of existing reserves and surplus of a company. It automatically increases the number of shares in the account of existing shareholders. The issue of bonus share does not in any case affect the 
resources base of the enterprise. It saves the company enormously of the hassles of capital issue (Gurusamy, 2011).

Gurung (2004) carried a study on growth and performance of securities market in Nepal and concluded that the primary market is poor in case of public issue in Nepal. He further stated this poor trend indicates public response on the liberalization and public participation policies of the government became ineffective except in a few sectors.

Kafle (2005) stated that the attraction of the primary market depends on an efficient stock exchange coupled with efficient clearing and settlement system. It needs modernization with good governance and automation of stock exchange. With the modernized stock exchange, the primary market is bound to increase manifold, providing a reliable and sustained alternative for raising capital.

SEBON (2005) carried a study on performance analysis of issue managers and concluded that banking and finance have occupied 74.92 percent of the total issue approval. There is dominance of equity share in the market as it has occupied 77.14 percent of the total investments available.

Dahal (2007) concluded that Nepalese IPOs have found to be heavily oversubscribed. It implies that the investors have a high degree of attraction to the IPOs. Based on 13 years data starting from FY 1993/94 to FY 2005/06, it was found that the growth of Nepalese IPOs in terms of issue and subscription has been bumpy. It shows the IPOs investors make 53.25 percent market adjusted returns leading to the conclusion that Nepalese IPOs are highly underpriced. IPOs returns have been affected mainly by the subscription times of issue and general returns of stock market. His study also reveals that the firm size expressed as the size of total assets affects the subscription times of issue positively and the debt-equity ratio affects the same negatively.

Pathak and Giri (2008) concluded that the trend of issuing rights share is increasing in Nepalese capital market where more than 50 percent investors like to subscribe rights share just to increase the number of shares. The under subscription of rights share is caused by various factors like lack of investor's awareness, low performance of companies and lack of adequate information. Price behaviors shown by the stock of sample organizations do not satisfy the theory of rights offering.

Gurung (2011) after his descriptive analysis of the data from 1993/94 to 2008/09 concluded that there is a weak presence of debentures and preference shares in the Nepalese capital market. Public interest in subscribing these securities is also not satisfactory. Debentures and preference shares are largely inactive and occupy lesser portion of the total capital market rather ordinary shares dominates the market indicating companies are yet to maintain optimum capital structure which adds value of the firm.

Mainali (2011) after statistically analyzing the data from Mid July 1994 to Mid July 2009, concluded that the stock market development is unable to show significant positive impact on the national economy. He also found that the results of primary data analysis indicate that the poor coordination among SEBON, NEPSE, NRB and Insurance Board in Nepal. Insufficient information of stock market, unavailability of CSD service, poor institutional 
strengthening of SEBON, low instrument diversification, mal-practices on stock transaction, frequent changes on policies, poor attraction of government for its development are the major problems of Nepalese stock market.

Gurung (2012) carried a study on initial public offerings and rights share issue practices in Nepal using 19 years data starting from 1993/94 to 2011/12. He concluded that Nepalese stock market has been dealing only with ordinary shares, right shares, debentures and preference shares. Ordinary shares and rights shares have dominant contribution in the total public floatation. The contribution of rights shares issue however, witnessed bullish in the public floatation at the later periods of the study.

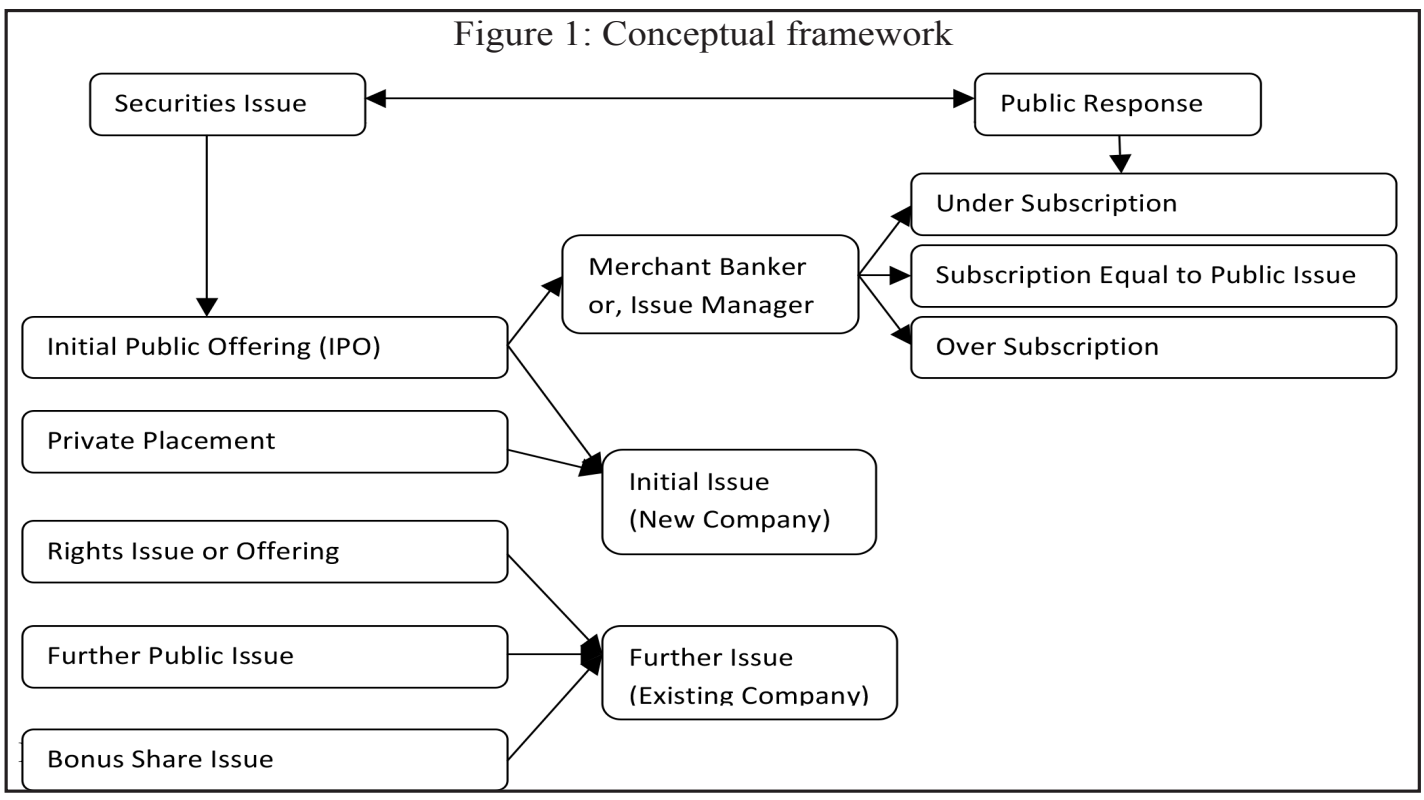

\section{Study Methods}

This paper is based on the secondary sources of data provided by various Nepalese capital market institutions. Most of the data employed in this study has been obtained from various issues of SEBON Annual Reports and Economic Survey of Ministry of Finance. The researcher has taken relevant data for the period of 22 years starting from 1993/94 to 2014/15 except the data of public subscription of ordinary shares. Statistical tools like descriptive statistics, line charts and bar graphs have been applied for the analysis of data in order to measure the status of public response to primary market in Nepal.

\section{Results and Discussion}

\section{Primary market indicators}

The primary market of stock is determined by various indicators such as total capital mobilization, ordinary share registration, approval of debenture issue, preference share 
registration, rights share registration, mutual fund registration, registration of citizens unit scheme, licensing and renewal of merchant bankers. This study has been basically emphasized towards the analysis of the status of primary market indicators that how they are contributing in the development of Nepalese stock market.

Capital mobilization: In present times stock markets indicate health of an economy. They are primary means of mobilization of long term savings and investment and fixed capital formation. Primary market, of course, mobilizes long term funds from surplus sectors to the deficit sectors through securities. In Nepal, the capital mobilization in the primary market through the issue of securities in 1993/94 was Rs. 244.4 million and reached at Rs. 2,785.4 million in 2006/07. Afterwards the trend of increment of capital mobilization increased sharply till $2009 / 10$ at Rs. $18,652.87$ million and started to decline sharply each year and reached at Rs. 8066.67 million in 2013/14. But in 2014/15 it started to increase and reached at Rs. 14,235.33 million. However, these status or trend of capital mobilization in the primary market indicate that the primary market in Nepal is getting bigger in size and there has been increasing capital investments in the productive sectors in the economy.

Figure 2 depicts the status or trend of capital mobilization in the primary market in Nepal.

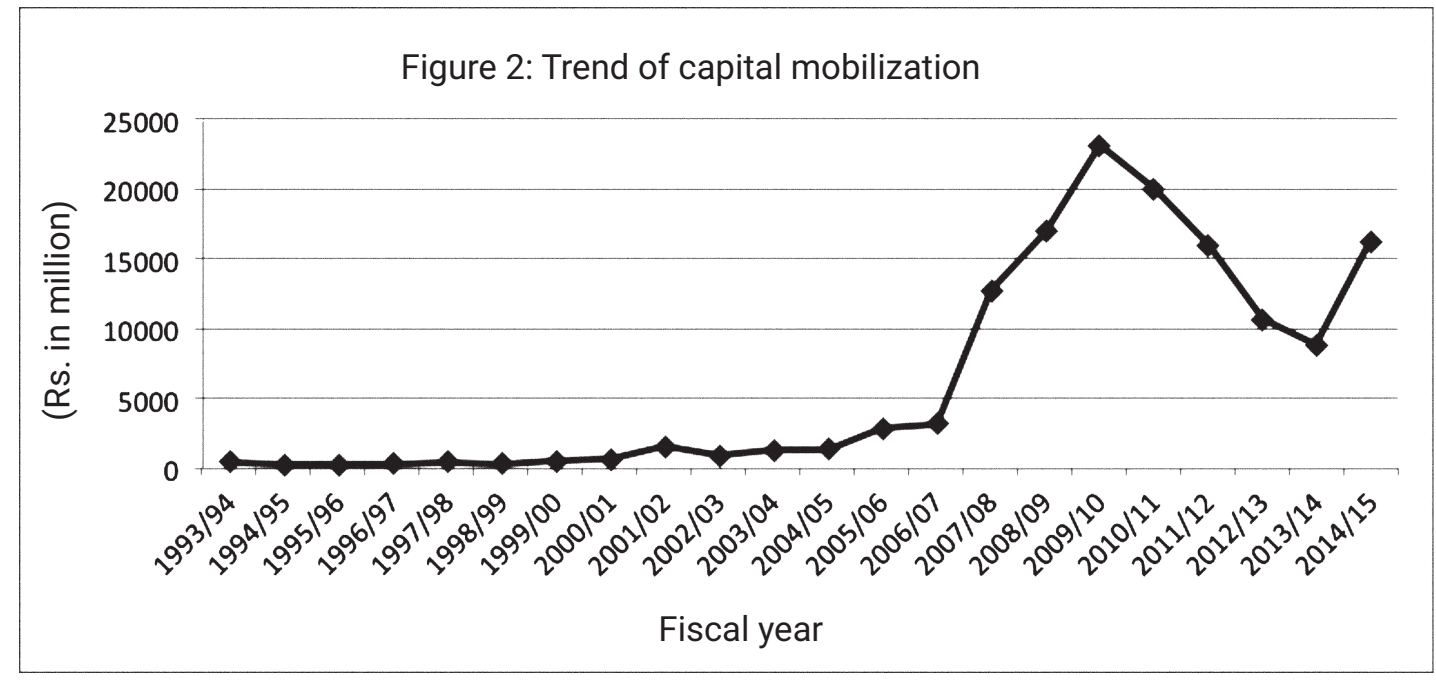

Source: Annual Reports of Securities Board of Nepal, 1993/94-2014/15 and Economic Surveys of Ministry of Finance, 1993/94-2014/15.

Ordinary share registration: Ordinary share is one of the basic capital market instruments for mobilizing capital in the economy. It provides the original and very foundation capital for the deficit sectors or organizations. It is the composition of both promoters' contribution as well as public at large. Merchant bankers arrange for issue registration of ordinary shares with SEBON (Bhattarai, 2064) and go for public. Normally issue of ordinary shares occupies a larger share in total issuance of securities in which the prospectus need to be published when shares are offered to the public or admitted to trading. 


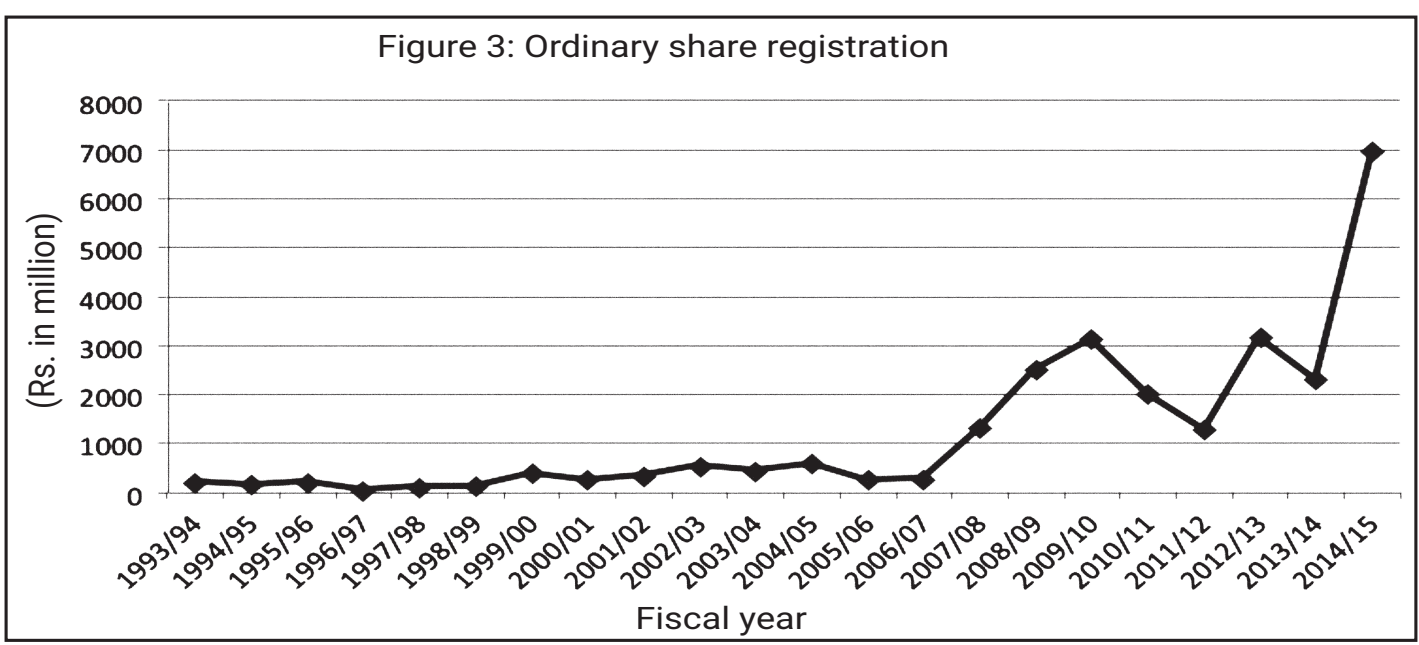

Source: Annual Reports of Securities Board of Nepal, 1993/94-2014/15 and Economic Surveys of Ministry of Finance, 1993/94-2014/15.

Figure 3 shows the ordinary share registration value in the primary market of Nepal. The ordinary share registration value in 1993/94 was Rs. 226.9 million and it kept on fluctuating and reached at Rs. 290.3 million in 2006/07. Afterwards this value sharply increased in each succeeding year till $2009 / 10$ at Rs. 3144.7 million and started to fall sharply in the next two years and reached at Rs. 1298.5 million in 2011/12. It has again kept on fluctuating but sharply boosted in 2014/15 at Rs. 6977.34 million and this value is considered as the highest value of ordinary share registration in SEBON during the period under study. The increasing trend on the value of ordinary share registration in the later years of the study implies the common stock market has becoming active as well as getting larger in size in Nepal and also people are gradually aware on investment in common stock.

Debenture approval: Debentures are fixed rate yielding securities issued by the corporate sector. The issuance of debenture is very popular in developed and developing countries like USA and India. Generally companies issue debentures to raise the debt fund through market mechanism (Bhattarai, 2064). But in Nepal only a few companies have raised the debt fund through market mechanism. However, debentures are floated only issuing prospectus. The approval of Company Registrar Office and SEBON on prospectus is essential to make public issue of debenture by issuing the prospectus.

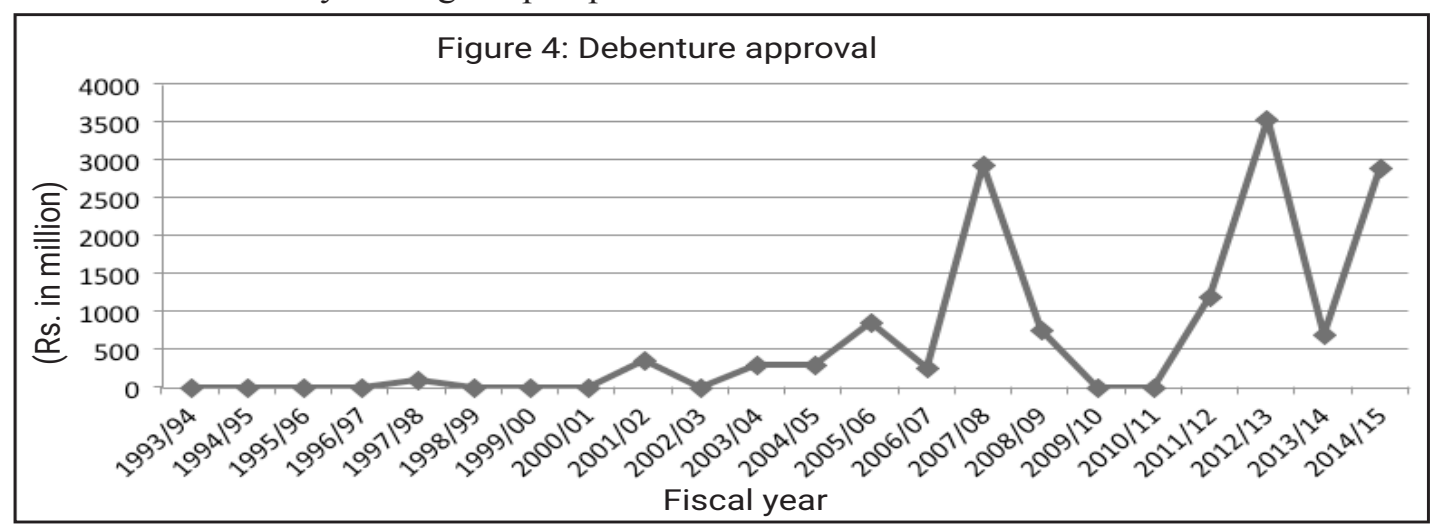


Source: Annual Reports of Securities Board of Nepal, 1993/94-2014/15 and Economic Surveys of Ministry of Finance, 1993/94-2014/15.

The issue approval of debenture value has been presented in Figure 4. The debenture issue approval started only in 1997/98 valued Rs. 93.0 million but it remained nil for the next three years too. In 2001/02 the debenture issue approval was Rs.360.0 million and also there were no issue approval of debentures in 2002/03 at all. Afterwards this value gradually increased in each year and reached at Rs. 2950.0 million in 2007/08. The value of debenture issue remained only Rs.750.0 million in 2008/09 and no issue at all during the succeeding two years. Then this value coupled coming in 2012/13 at Rs. 3550.0 million which is the highest value of debenture issue approval during the period under study. The approval of debenture issue still remain fluctuated and slumped at Rs. 700.0 million in 2013/14 and again picked up at Rs. 2900.0 million in 2014/15. These facts indicate that the debenture market in Nepal is inactive and not systematic. The number of debentures being issued in the Nepali capital market is low compared to other instruments of capital financing of corporate sector.

Right share registration: A part of ordinary share which are issued after the original issue of shares but having an inherent right of the existing shareholders to subscribe at par to these shares in proportion to their holding. The offer of this type of shares shall be made in the form of a notice giving the particulars of shares offered and stating time limit of the offer for acceptance of such offer. These shares can also be issued to the new members on auction when the existing shareholders do not accept the offer within a stipulated time period. However, before its issuance, the issuing company requires to get issue approval from SEBON through their registration.

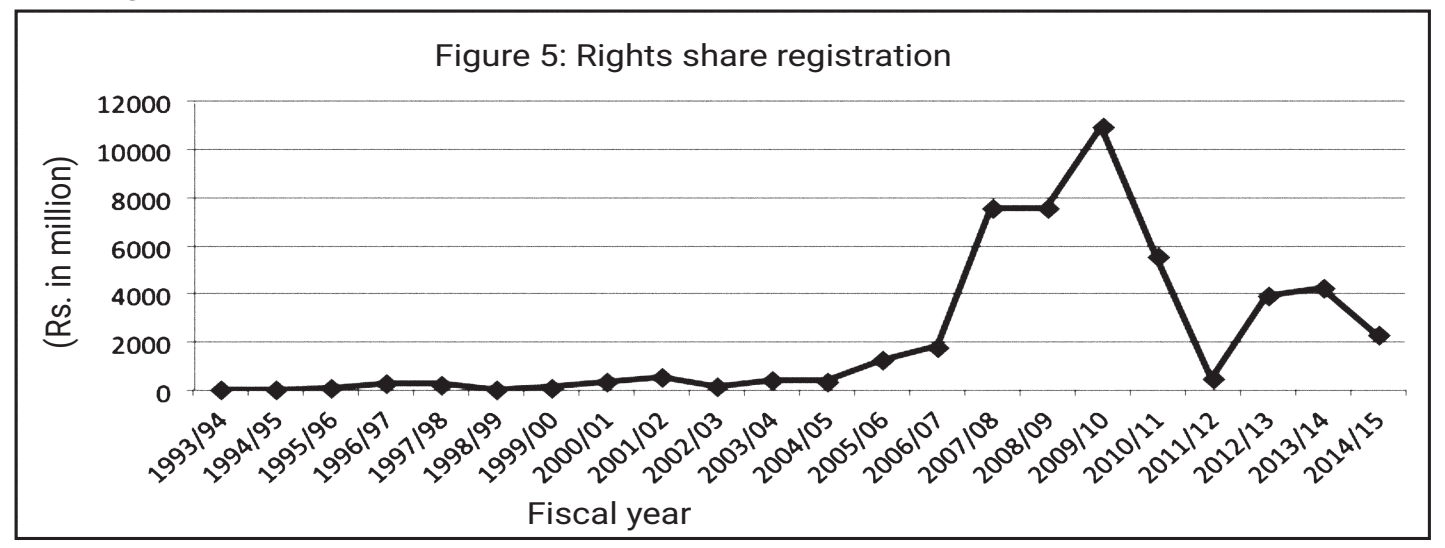

Source: Annual Reports of Securities Board of Nepal, 1993/94-2014/15 and Economic Surveys of Ministry of Finance, 1993/94-2014/15.

Figure 5 reveals the trend of rights share registration value during the different periods. Since 1995/96 the right share registration and issue started in Nepal which was valued at Rs. 69.0 million. But it remained fluctuating during the different periods with smaller values and continued till 2004/05. Afterwards it has continuously increased in each year and reached at Rs. 10962.75 in 2009/10 which is highest during the period under study and then sharply decreased and reached at Rs.451.68 million in 2011/12. But thereafter it again started to increase with a value of Rs. 3935.2 million and Rs. 4243.13 million in 2012/13 and 2013/14 
respectively but slightly decreased and reached at Rs. 2307.99 million in 2014/15. These trend clearly indicate that the practice of right share registration and issue in later periods is improving implying companies are getting larger in their size. On the other hand, Nepal Rastra Bank's mandatory provision of increasing firms' paid up capital even through right share issue and/or any other means is the evidence for increasing the value of right share registration in Nepal.

Registration of other securities: There are many other capital market instruments like preference shares, mutual funds, citizen unit scheme as well as bonus share that the corporate sector may use in order to raise long term capital as per their requirements. While issuing these securities, firms' should get approval from SEBON through their registration. Preference share registration was rare and also their value was very poor in Nepal. The registration and issue of preference share was started in 1993/94 valued at Rs. 16.5 million then in 1998/99 at Rs. 80.0 million. The value of preference share registration was Rs. 140.0 million in 2001/02 and Rs. 400.0 million in 2006/07. These indicate that preference shares are rarely practiced in corporate sector in order to raise long term capital in Nepal resulting its negligible presence in primary market. . Though it is cheaper source, firms should pay preference dividend at fixed rate, than ordinary shares this capital market instrument is most neglected in Nepal.

Mutual fund which is also considered as the means of diversified investment scheme from the investors point of view should also get registered in SEBON. It is essentially a mechanism of pooling together the savings of a large number of investors for collective investments with the objective of attractive yields and appreciation in their value (Gurusamy, 2009). The value of mutual funds registration was Rs. 100.0 million in 1993/94 and also in 2002/03. It was Rs. 45.49 million in 2004/05 and reached at Rs. 2050.0 million in 2014/15. Similarly, citizen unit scheme was registered only in two years during the study period such as Rs. 50.0 million in 1994/95 and Rs. 62.87 million in 2003/04. These facts indicate that the alternative means of raising long term capital like preference shares, mutual funds and citizen unit scheme have given least priority in the primary capital market in Nepal though they may contribute in developing optimum capital structure of corporate sector. In real sense, the use of these alternative sources of capital is still slow and negligible in the overall market mechanisms. Only 13 merchant bankers have been holding the total primary market of Nepal in which some are even not in operation. This fact also indicates the size of primary market is small though the public interest towards the market tends to increase.

Relationship between total capital mobilization and ordinary share registration: Figure 6 shows the relationship between total capital mobilization and ordinary share registration. The trend line shows the similar trend throughout the study period. The gap is becoming wider in the later periods mainly due to high volume of registration of rights share. Since 1993/94 till 2006/07 the trends of total capital mobilization and ordinary share registration is somehow similar but fluctuating slightly. Afterwards, both of them started to increase manifold and total capital mobilization reached at Rs. 23198.29 million whereas ordinary shares registration valued at Rs. 3144.7 million in 2009/10. Thereafter they remain fluctuating in decreasing trend till 2014/15. This indicates that the capital mobilization in the primary market is increasing during the period under study. 


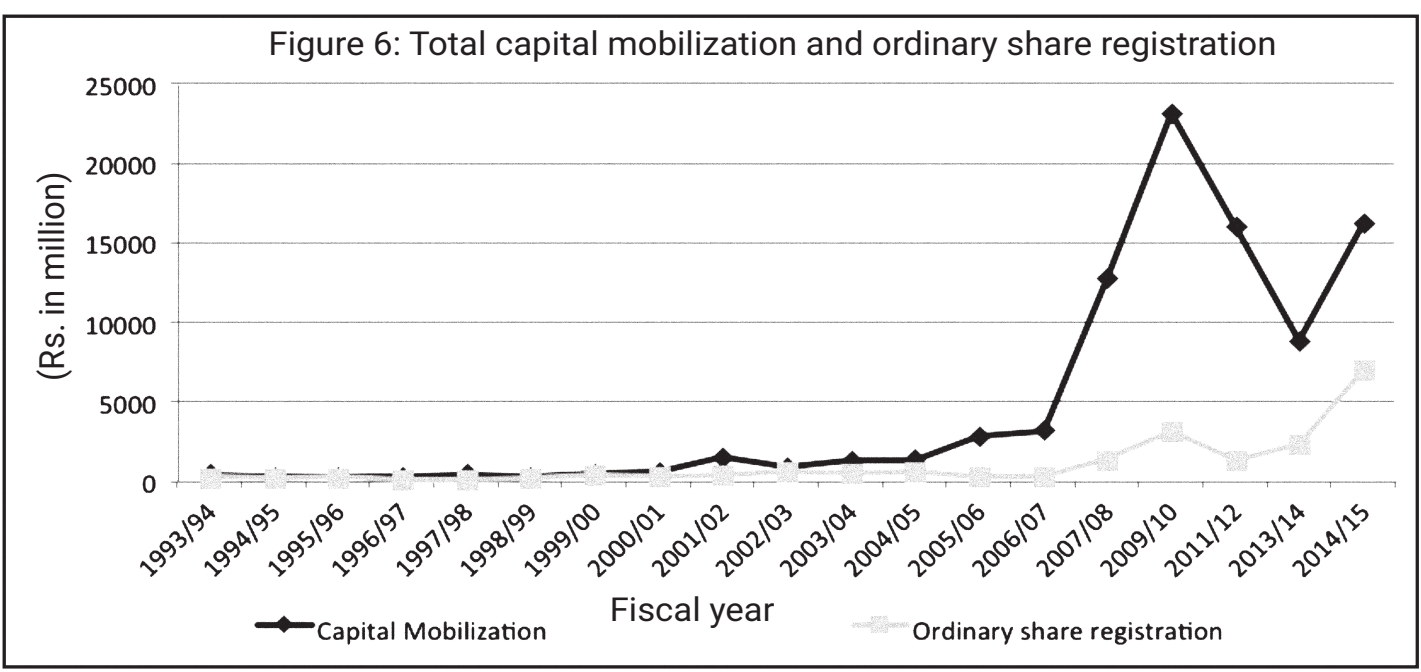

Source: Annual Reports of Securities Board of Nepal, 1993/94-2014/15 and Economic Surveys of Ministry of Finance, 1993/94-2014/15.

Relationship between registration of ordinary share and approval of debentures: Figure 7 depicts the values of ordinary share registration and approval of debentures for the period of 22 years. This reveals that the ordinary share registration and issue has been continuous and gradually increasing since the establishment SEBON whereas the approval of debenture started only from 1997/98. Debenture approval and issue remain infrequent during the period under study. This indicates that the registration of securities for public issue is highly dominated by ordinary shares and debenture issue seems unsystematic presence in the primary market in Nepal. In other words, the market of ordinary shares is more active than that of the market of debenture. Firms have not been able to maintain proper mix of equity and debt capital in their capital structure.

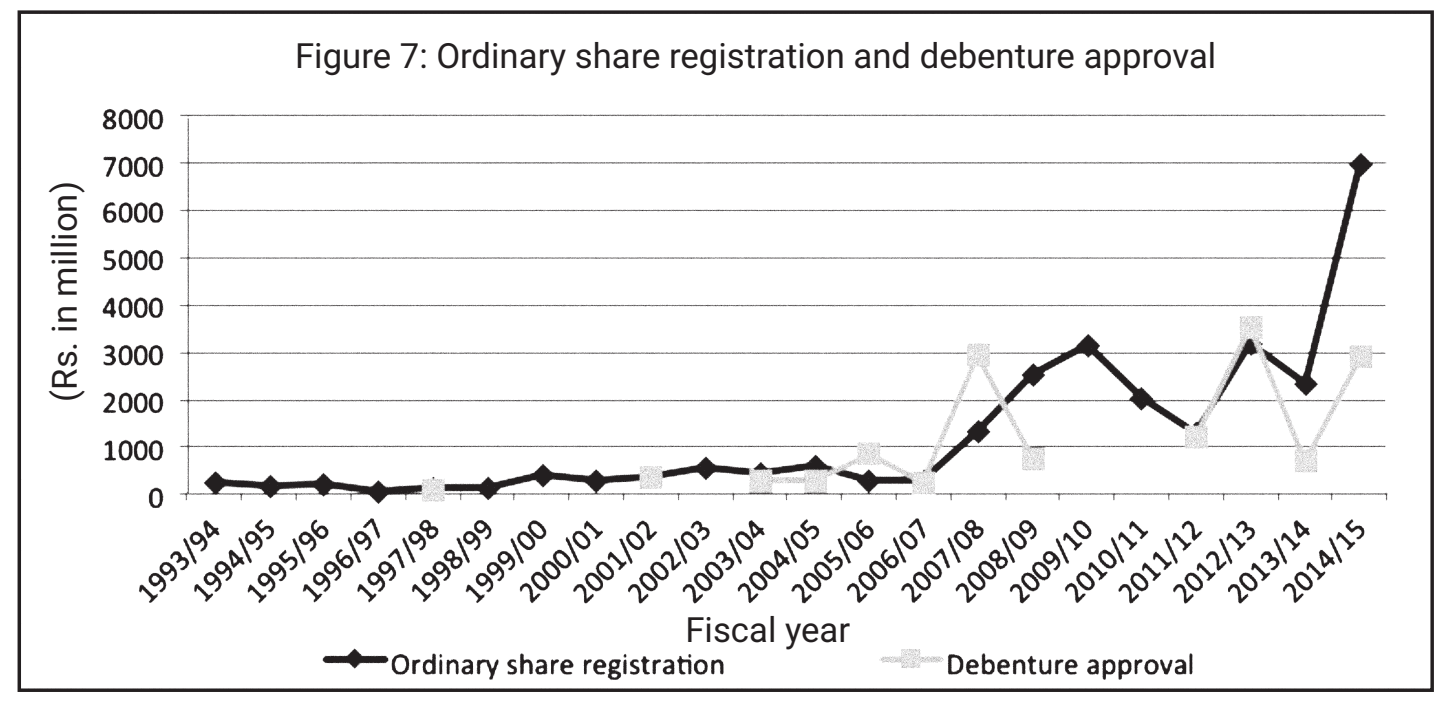

Source: Annual Reports of Securities Board of Nepal, 1993/94-2014/15 and Economic Surveys of Ministry of Finance, 1993/94-2014/15. 
Relationship between ordinary share and right share registration: Figure 8 depicts the values of ordinary shares and rights shares registration and their relationships. This reveals that ordinary share registration was started since 1993/94 whereas registration of right shares began from 1995/96. The values of their registration and issue have been somehow similar till 2004/05. Afterwards, the registration of right shares has been rapidly increased and picked at Rs. 10962.75 million in 2009/10 whereas ordinary share registration has slowly increased and reached at Rs. 3144.7 million in the same year. But both of them have slumped in succeeding two years at the lowest level then started to increase though they have been fluctuating. During 2005/06 to 2010/11 the value of right share registration was heavier than the registration of ordinary shares implying firms have tried to enhance their capital base within and shareholders have tried to maintain their control in the firms.

However, both the securities are ordinary shares whereby registration of ordinary shares mobilizes fresh capital from the public but right share issue is used to raise additional capital from the existing equity shareholders. Both of them help to raise equity capital of the firms.

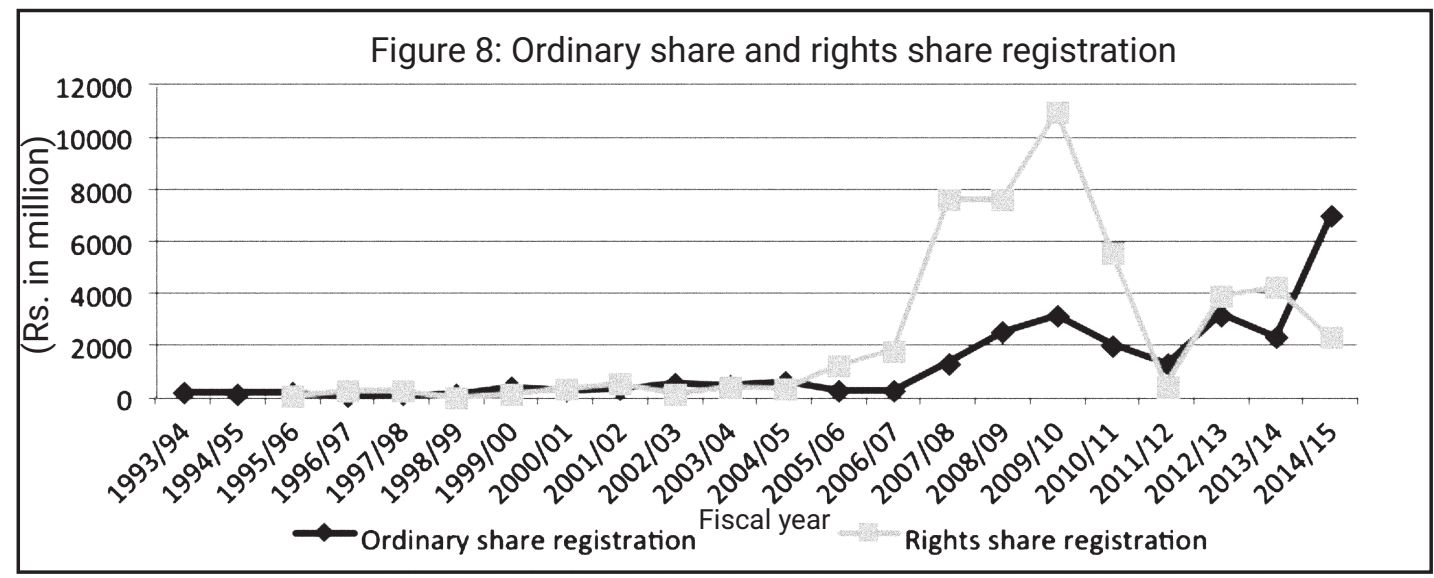

Source: Annual Reports of Securities Board of Nepal, 1993/94-2014/15 and Economic Surveys of Ministry of Finance, 1993/94-2014/15.

Over and under subscription of ordinary shares: When the demand of securities is higher than IPOs, the situation is called the case of oversubscription but if the demand of securities is lower than IPOs such a situation is called under subscription of securities.

During the period of $2001 / 02$ to $2014 / 15$, out of the total registered companies only 222 companies offered their IPOs especially ordinary shares for public subscription and among them IPOs of 218 companies (98.2 percent) have been oversubscribed whereas IPOs of two companies ( 0.90 percent) have been undersubscribed and remaining two companies (0.90 percent) issue have been hundred percent subscribed (See Appendix).

In the year 2001/02, nine companies issued their ordinary shares for public subscription out of which shares of seven companies have been oversubscribed and undersubscribed for only two companies. Afterwards securities were oversubscribed for all the years till 2007/08. Subscriptions of ordinary shares of two companies were equal to the issued volume out of total 18 companies and remaining was oversubscribed. Since then securities were oversubscribed till 2014/15. During the period under study, 37 companies issued their ordinary shares for 
public subscription in year 2009/10 which is the highest issue and fully oversubscribed whereas only five companies issue their ordinary shares for public subscription in 2004/05.

These facts indicate that the public response on share subscription is highly significant during the study period. This also implies that the ordinary share market is more active, dynamic and vibrant in Nepal. People are more eager and motivated to buy shares of corporate houses as their awareness on long term investment has been so miraculous. This kind of superior trend of public subscription is also considered as the symbol of opting economy towards growth at large through productive investments.

\section{Conclusion}

The liberalization policy which was initiated in the beginning of 1990s then establishment of SEBON in 1993 has brought radical changes in the capital market mechanisms in Nepal but the performance of primary market has not been so pronounced as expected in about first one and half decades. Thereafter the total capital mobilization in the primary market tends to increase indicating increasing size of capital market in Nepal. This trend also indicates that there is growing number of companies and expansion of corporate houses in their sizes and activities resulting increasing capital formation in the economy.

The ordinary shares registration has shown the same trend as in the total capital mobilization. Debenture issue approval has been found irregular and vulnerable during the study period. Registration and issuance of other securities like preference shares, mutual funds and citizen unit scheme have not seen attractive indicating public response on these securities is poor. These facts imply that Nepalese primary market is highly dominated by the ordinary share which is most risky instrument. However, securities other than ordinary shares need to be more innovative in order to meet the funding needs of the company which helps developing an optimum capital structure that also match the investment preference of the investors creating appropriate investment portfolios of their own.

In the total capital mobilization, the contribution of right share registration has been more significant whereas IPOs registration decreases in the later periods of the study. These indicate that the stock market is bearish as macro economic variables are becoming stronger. Moreover, ordinary shareholders also have the right to influence company management through the election of a company's board of directors as a result firms manage their required funds from the existing shareholders through rights issue. Heavier rights share registration could be the strategy of internal expansion and diversification of existing firms.

Looking at the public subscription of securities, Nepalese IPOs have been found to be heavily oversubscribed which is dominated by ordinary shares during the study period. It shows that the investors have a very high degree of attraction to the IPOs. The study shows that the growth of Nepalese IPOs in terms of number of issuing companies and percentage of subscription, it is bumpy during the study period. This trend indicates that IPOs are sold at a significant discount, a phenomenon known as under pricing. The deeper the under pricing, the higher will be the initial returns resulting into the better performance of IPOs for the investors. On the other hand, the deeper the under pricing, the lesser will be the net proceeds 
for the issuing companies resulting into the loss of wealth of the company as it represents the part of the cost of going public for the companies (Dahal, 2007).

The status of public response of ordinary shares is found satisfactory in the primary market though it has some shortcomings. But the market for other securities still needs to be more organized which requires reformulating the existing policy that can make the market more public friendly. Licensing to new merchant bankers needs to be extended which makes their performance more competitive and public friendly. Such effort, by and large, will promote the primary market of securities so the companies may have many alternative sources of raising funds that help add value by minimizing risk and cost of managing funds.

\section{BIBLIOGRAPHY}

Bhattarai, P. (2064 BS). Capital market in Nepal. Kathmandu: Bhudipuran Prakashan.

Dahal, G. B. (2007). The performance of Nepalese IPOs. SEBON Journal III, 30-48.

Gitman, L. J., \& Joehnk, M. D. (2012). Fundamentals of investing (10 ${ }^{\text {th }}$ ed.). New Delhi: Dorling Kindersley.

Gurung, J. B. (2004). Growth and performance of securities market in Nepal. The Journal of Nepalese Business Studies I(1), 85-92.

Gurung, J. B. (2011). Status of debentures and preference shares issue in Nepal. Pokhara Management Review (2), 65-70.

Gurung, J. B. (2012). Initial public offerings and rights share issue practices in Nepal. Pokhara Management Review (3), 49-58.

Gurung, J. B. (2013). Bonus shares issue and listing trends in Nepal. Pokhara Management Review (4), 99-106.

Gurusamy, S. (2009). Indian financial system (2 ${ }^{\text {nd }}$ ed.). New Delhi: Tata McGraw Hill Education. Gurusamy, S. (2011). Capital markets (2 ${ }^{\text {nd }}$ ed.). New Dehli: Tata McGraw Hill Education.

Kafle, D. R. (2005). Primary market development in Nepal: Issues and challenges. SEBON Journal II, 25-33.

Machiraju, H. R. (1998). Indian financial system. New Delhi: Vikas Publishing House.

Mainali, P. K. (2011). Problems and prospects of stock market in Nepal. SEBON Journal V, 35-58. Mukharjee, A., \& Hanif, M. (1998). Modern accountancy II. New Delhi: Tata McGraw-Hill Publishing Company.

Pathak,H. P., \& Giri, D. (2008). Rights share issue practices in Nepal. The Journal of Nepalese Business Studies V(1), 93-100.

Paudel, R. B., Baral, K. J., Gautam, R. R. \& Rana, S. B. (2013). Financial management. Kathmandu: Ashmita Books Publishers and Distributors.

Raghunathan, V. (1995). Stock exchanges and investment ( $2^{\text {nd }}$ ed.). New Delhi: Tata McGrawHill Publishing Company.

Securities Board of Nepal (2005). Performance analysis of issue managers. SEBON Journal II, Kathamandu: Author. 


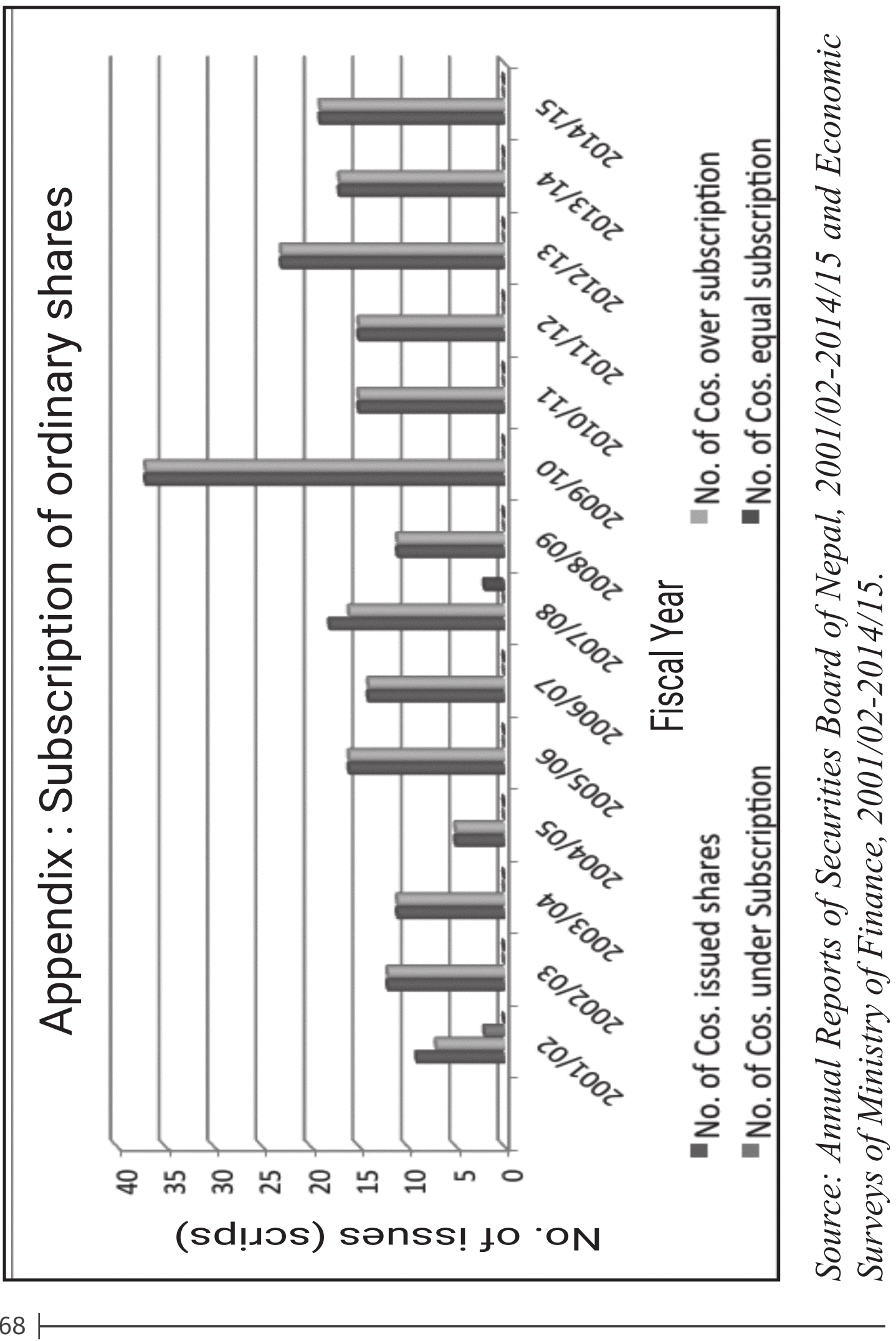

